УДК 330.3:332.122

JEL classification: $R 58$

Тульчинська С.O.

доктор економ. наук, професор

ORCID ID: 0000-0002-1409-3848

Кириченко С.О.

канд. економ. наук

ORCID ID: 0000-0001-6195-5204

Національний технічний університет Украйни

«Київський політехнічний інститут імені Ігоря Сікорського»

\title{
ДОСЛІДЖЕННЯ МЕТОДИЧНИХ ПІДХОДІВ ДО ОЦНЮВАННЯ РОЗВИТКУ СОЦІАЛЬНОЇ ІНФРАСТРУКТУРИ В РЕГІОНАХ
}

\section{ИССЛЕДОВАНИЕ МЕТОДИЧЕСКИХ ПОДХОДОВ К ОЦЕНИВАНИЮ РАЗВИТИЯ СОЦИАЛЬНОЙ ИНФРАСТРУКТУРЫ В РЕГИОНАХ}

\section{RESEARCH METHODICAL APPROACH ASSESSMENT OF REGIONAL SOCIAL INFRASTRUCTURE}

Аналіз існуючих методччних підходів очінки розвитку соџіальної інфраструктури дало можливість визначити їх позитивні та негативні сторони та встановити, щоо: поперше, частіше всього дослідники використовують, для оцінки поточного стану сочіальної інфраструктури та змін ї̈ динаміки по рокам метод агрегатного індексування. По-друге, для очінки саме розвитку доречно використовувати такі статистичні методи: як коефіиієнт варіації, дисперсію, середньоквадратичне відхилення, а також методи групування, стандартизаиї показників, визначення сумарних та інтегральних показників тощьо. По-третє, незважаючи на те, щуо для оцінки розвитку сочіальної інфраструктури та ї̈ підсистем використовують різноманітний методичний інструментарій дослідження, можна зазначити відсутність у методиках орієнтачії на встановлення певних залежностей розвитку системи, щзо у сучасних умовах економічної дестабілізачії набуває особливоі актуальності. По-четверте, більшість методичних підходів очінки розвитку сочіальної інфраструктури регіонів базуються на використанні інструментарію визначення інтегральної оцінки за різними показниками, які об’єднані у певні підгрупи, щзо характеризують багатоаспектні прочеси сочіальної інфраструктури. По-п'яте, після оцінки стану розвитку соиіальної інфраструктури в регіонах, для розроблення подальших варіантів розвитку, з урахуванням регіональної специфіки й впливу зовнішніх факторів, прийняття управлінських рішень, заходів пожвавлення розвитку соціальної інфраструктури, особливе місце займає використання методів економіко-математичного моделювання.

Встановлено, що загальними рисами досліджуваних методів оцінки розвитку соціальної інфраструктури є те, щуо: вони базуються на виділенні часткових груп показників, які характеризують систему у иілому, розраховується інтегральний показник розвитку сочіальної інфраструктури, здійснюється ранжування регіонів за рейтингом у залежності від отриманих результатів, щзо допомагає при розробленні стратегії розвитку на основі сформульованих прогнозів та визначенні заходів, які забезпечують їх реалізацію.

Аналіз найбільш часто вживаних показників, щзо використовуються для оиінки соціальної інфраструктури дає можливість стверджувати, щуо частіш за все ці показники є 
показниками які наводяться Державним управлінням статистики та не існує єдиного загально визначеного набору часткових показників для оцінки сочіальної інфраструктури.

Ключові слова: соціальна інфраструктура, регіон, методи, методичні підходи, оцінка, розвиток, часткові показники

Анализ существвующих методических подходов оценки развития социильной инфраструктуры позволил определить их положительные и отрицательные сторонь, а также установить, что во-первых, чаще всего исследователи используют для оценки текущего состояния сочиальной инфраструктуры и изменений ее динамики по годам метод агрегатного индексирования. Во-вторых, для оценки именно развития уместно использовать такие статистические методь как коэффициент вариачии, дисперсию, среднее отклонение, а также методы группировки, стандартизации показателей, определения суммарных и интегральных показателей и тому подобное. B-третьих, несмотря на то, что для оченки развития сочиальной инфраструктуры и ее подсистем используют иирокий методический инструментарий исследования, можно отметить отсутствие в методиках ориентации на установление определенных зависимостей развития системы, что в современных условиях экономической дестабилизачии приобретает особую актуальность. В-четвертых, большинство методических подходов оценки развития социальной инфраструктуры регионов базируются на использовании инструментария определения интегральной оценки по различным показателям, которые объединены в определенные подгруппы, характеризующие многоаспектные прочессы сочиальной инфраструктуры. В-пятых, после оценки состояния развития сочиальной инфраструктуры в регионах, для разработки дальнейших вариантов развития, с учетом региональной специфики и влияния внешних факторов для принятия управленческих решений и создания мероприятий по оживлению развития социальной инфраструктуры, особое место занимает использование методов экономико-математического моделирования.

Установлено, что общими чертами исследуемых методов оценки развития соичиальной инфраструктуры является то, что они базируются на выделении частных групп показателей, характеризующих систему в целом; рассчитывается интегральный показатель развития сочиальной инфраструктуры; осуществляется ранжирование регионов по рейтингу в зависимости от полученных результатов.

Анализ наиболее часто применяемых показателей, используемых для оценки соичильной инфраструктуры, дает возможность утверждать, что чаще всего эти показатели являются показателями которые приводятся Государственным управлением статистики и не существует единого общего определенного набора частных показателей для оценки соичильной инфраструктурыл.

Ключевые слова: социальная инфраструктура, регион, методы, методические подходы, оценка, развитие, частичные показатели

Analysis of existing methodological approaches assess the development of social infrastructure made it possible to identify their positive and negative sides and establish that: first, often researchers use to assess the current state of social infrastructure and changes its dynamics by years of aggregate indexing method. Second, to assess the development is appropriate to use such statistical methods: the coefficient of variation, variance, standard deviation, and methods of grouping, standardization of indicators, determination of total and integral indicators and so on. Third, despite the fact that for the assessment of social infrastructure and its sub-systems using various methodological tools of research, we note the 
lack of techniques focus on the establishment of certain dependencies of a system that modern conditions of economic destabilization of particular relevance. Fourth, most methodological approaches assessment of social infrastructure in the region based on the use of tools for integrated assessment determining various parameters, which are combined in specific subgroups that characterize the multifaceted processes of social infrastructure. Fifth, after the assessment of the development of social infrastructure in the regions, to develop options for further development, taking into account regional specifics and external factors, management decisions, actions recovery of social infrastructure, a special place is the use of methods of economicmathematical modeling.

Established that the general characteristics of the studied methods for assessing social infrastructure development is that they are based on the allocation of partial sets of indicators that characterize the system as a whole, calculated integral index of social infrastructure, carried Rankings regions rated depending on the results, which helps when designing the development strategy formulated on the basis of forecasts and identify measures that ensure their implementation.

Analysis of the most frequently used indicators used to assess the social infrastructure provides an opportunity to state that most often these indicators are indicators which are listed by the State Statistical Office and there is no single commonly defined set of partial indicators to assess social infrastructure.

Keywords: social infrastructure, region, methods, teaching approaches, assessment, development, partial indicators

Вступ. Соціальна інфраструктура $є$ одним 3 домінуючих факторів впливу на відтворювальний потенціал в регіонах та підвищення якості життя населення.

Вагомі здобутки у дослідженні багатогранних проблем розвитку соціальної інфраструктури в регіональній економіці представлені у роботах таких вітчизняних вчених: О. М. Алимова, А. А. Багдаєва, Б. М. Данилишина, Є. Л. Логінова, А. А. Мазаракі, М. К. Орлатого, Ю. І. Саєнка та ін. Розробленню методів визначення розвитку соціальної інфраструктури в регіонах присвячено роботи багатьох науковців, а саме: I. О. Абрамова [1, с. 8], С. І. Бондара [3, с. 6], В.П. Дубіщева [4, с. 61], А.В. Лісового [5, с. 54], О. І. Омельченко [6, с. 83], М. В. Панько [7, с. 180]; О.А. Подіка [8, с. 56]; В. М. Прохорова [4, с. 61]; М. Г. Саєнко А. П. Сава [9, с. 268]; В.В. Соляра [10, с. 203]; Л.Л. Сотниченко [11, с. 337]; Л.Г. Чернюк та Т.В. Пепи [12, с. 14] та iн.

Незважаючи на значну кількість публікацій, визначення методичного підходу щодо оцінки розвитку соціальної інфраструктури на регіональному рівні залишається дискусійним та не вирішеним, що спонукає до подальшого дослідження цього питання. Оскільки в сучасних умовах економічної дестабілізації важливим є дослідження існуючих методів та моделей оцінки розвитку соціальної інфраструктури регіонів 3 метою їх удосконалення, це надасть можливість більш комплексно та системно підійти до проблем іï розвитку. Без оцінки розвитку соціальної інфраструктури неможливо 
розробити заходи щодо активізації іiі розвитку, що зумовлює актуальність проведення аналізу існуючих методик оцінки розвитку соціальної інфраструктури та потребує подальших досліджень та пропозицій 3 удосконалення методів оцінки розвитку соціальної інфраструктури регіонів.

Постановка завдання. Метою дослідження $\epsilon$ аналіз існуючих методичних підходів оцінки розвитку соціальної інфраструктури регіонів для врахування їх позитивних та негативних сторін при удосконаленні методичного підходу щодо оцінки розвитку соціальної інфраструктури регіонів.

Для вирішення поставленої мети були окреслені такі завдання:

- проаналізувати існуючі методичні підходи оцінки розвитку соціальної інфраструктури регіонів;

- проаналізувати використання часткових показників у методичних підходах до оцінки рівня розвитку соціальної інфраструктури регіонів;

- визначити позитивні та негативні сторони існуючих методичних підходів оцінки розвитку соціальної інфраструктури для їх врахуванні при удосконаленні методичного підходу до оцінки розвитку соціальної інфраструктури регіонів.

Методологія. Під час проведення дослідження було використано загальнонаукові прийоми досліджень та специфічні методи, що грунтуються на сучасних наукових засадах економічної науки. А саме:

- аналізу та синтезу - для виокремлення специфічних ознак розроблених методик оцінки розвитку соціальної інфраструктури регіонів;

- порівняльний метод - для визначення позитивних та негативних сторін методик оцінки розвитку соціальної інфраструктури;

- логічний метод та метод узагальнень - для надання відповідних висновків та практичних рекомендацій щодо розроблення методичного підходу до оцінки розвитку соціальної інфраструктури регіонів.

Результати дослідження. Аналітичний центр «Бюро економічних та соціальних досліджень» [2] спільно з Регіональним представництвом Фонду ім. Фрідріха Еберта в Україні та Поліським фондом міжнародних досліджень, в межах проекту «Стан та перспективи розвитку інфраструктури регіонів», дослідили інфраструктуру регіонів в Україні. При цьому дослідження було проведено тільки за 2013 рік без порівняння розвиненості інфраструктури в різних регіонах України. Але, для нашого дослідження, інтерес викликають показники, які були обрані для оцінки стану інфраструктури в регіонах. А саме було досліджено стан таких дев'яти підсистем:
1) транспортної (7 показників);
2) зв'язку (6 показників);
3) екологічної (2 показника);
4) рекреаційної (6 показників); 
5) житлово-комунального господарства (3 показника);

6) освіти (10 показників);

7) медичної (4 показника);

$8)$ соціального забезпечення (5 показників);

9) культурної (6 показників).

Необхідно відзначити, що у дослідженні, при оцінці інфраструктури в регіонах, показники підсистем відрізнялися. Деякі дані були наведені за попередні роки від 2013 року. Інколи показники порівнювалися із минулими роками.

О.А. Подік [11, с. 56] визначає рівень розвитку соціальної інфраструктури «як цілісну систему рівнів розвитку окремих іiі структурних підвидів», а саме сумою його складових за формулою:

$$
\mathrm{I}=\sum_{i=1}^{N} k_{i} \times I_{i}
$$

де: $I$ - загальний рівень розвитку соціальної інфраструктури;

$I_{i}$ - окремі види соціальної інфраструктури;

$N$ - число окремих видів соціальної інфраструктури;

$k_{i}$ - ваговий коефіцієнт для кожного виду соціальної інфраструктури.

На думку О.А. Подіка такі розрахунки визначають рівень розвитку соціальної інфраструктури та показують, наскільки збільшилось або зменшилось виробництво продукції завдяки розвитку окремих складових інфраструктури. Окремі індекси показників-стимуляторів розвитку соціальної інфраструктури розраховуються індексним методом за формулою:

$$
\mathrm{I}_{\mathrm{k}}=\frac{R_{i}-R_{\min }}{R_{\max }-R_{\min }},
$$

де $\mathrm{I}_{\mathrm{k}}$ - показник впливу на розвиток соціальної інфраструктури;

$R_{i}$ - значення показника і-го району;

$R_{\text {min }}$ - мінімальне значення показника;

$R_{\max }$-максимальне значення показника.

На наш погляд, необхідно погодитися 3 автором відносно того, що рівень розвитку соціальної інфраструктури необхідно розглядати як цілісність iї структурних елементів, а також $з$ тим, що, безумовно, розвиток соціальної інфраструктури впливає на виробництво продукції. Але, необхідно наголосити, що сумарний індекс, який визначається за формулою (1) не характеризує сам «розвиток» і не показує його динамічних змін, а для того, щоб «визначити вплив кожного елементу соціальної інфраструктури на виробництво додаткової одиниці продукції» недостатньо визначити індекси 
показників-стимуляторів розвитку за формулою (2). Для цього необхідно визначати $\Delta \mathrm{I}_{\mathrm{K}}-$ зміну у розвитку та його вплив на $\Delta-$ додатковий випуск продукції.

А. Лісовий [6, с. 54], при дослідженні розвитку соціальної інфраструктури, виходить 3 того, що часткові показники повинні використовуватися у відносних значеннях. При цьому необхідно використовувати їх бальну оцінку. Узагальнений показник розвитку соціальної інфраструктури (I) розраховують за допомогою інтегрального показника, використовуючи при цьому коефіцієнт пріоритетності $i$-го виду послуг $\left(q_{i}\right)$, який визначається за допомогою експертних оцінок:

$$
\mathrm{I}=\sum_{i=1}^{m} \frac{f_{i}}{n_{i}} \cdot q_{i},
$$

де $f_{i}$ - фактична забезпеченість і-тим видом послуг;

$n_{i}$ - нормативна забезпеченість і-тим видом послуг.

Думку про те, що необхідно використовувати вагові коефіцієнти поділяє C.I. Бондар [3, с. 6], який пропонує загальний рівень розвитку соціальної інфраструктури (П) розраховувати як:

$$
\Pi=\sum_{i=1}^{N} k \cdot \Pi_{i},
$$

де $\Pi_{i}$ - окремі види соціальної інфраструктури;

$N$ - число окремих видів інфраструктури;

$k_{i}$ - ваговий коефіцієнт для кожного виду соціальної інфраструктури.

C.I. Бондар як і О.А. Подік [11, с. 56] (див. формулу 2) пропонує розраховувати індекси показників-стимуляторів $\left(I_{K}\right)$, тобто показників, що характеризують позитивні соціально-економічні явища. Необхідно відзначити, що при використанні коефіцієнту пріоритетності досить складно уникнути суб'єктивізму при експертній оцінці, а інтегральний показник, по суті $\epsilon$ сумарним. Для того щоб усунути суб'єктивізм при використанні коефіцієнту вагомості, що визначається на основі експертної оцінки, на наш погляд, доречно використати коефіцієнт конкордації $(W)$ :

$$
W=\frac{12 \cdot S}{L^{2} \cdot\left(n^{3}-n\right)},
$$

де $S$ - сума квадратів відхилень підсумків оцінок кожного часткового показника розвитку соціальної інфраструктури;

$L$ - кількість експертів; 
$n$ - кількість оціночних показників.

Коефіцієнт конкордації дорівнює 1, якщо вага ранжування експертів однакова, і дорівнює 0, якщо при ранжуванні абсолютно немає збігу.

О. Ляшенко [7, с. 114] удосконалив методику визначення рівня розвитку соціальної інфраструктури району. Інтегральний показник рівня розвитку соціальної інфраструктури району $\left(C_{j}\right)$ розраховується за формулою:

$$
\mathrm{C}_{\mathrm{j}}=\frac{\sum K_{i j} \cdot W_{i j}}{n}+\frac{\sum K_{i j}^{\prime} \cdot W_{i j}^{\prime}}{n},
$$

де $K_{i j}$ - показник рівня розвитку і-го виду послуг у $j$-му районі;

$K_{i j}$ - показник доступності $i$-го об'єкту послуг у $j$-му районі,

$W_{i j}^{\prime}$ - вага і-го виду послуг у $j$-му районі;

$W_{i j}$ - вага доступності $i$-го виду послуг у $j$-му районі;

$n$ - число душових показників та показників доступності за умови використання неоднакової їх кількості.

Для розрахунку рівня розвитку соціальної інфраструктури району О. Ляшенко використовує такі показники як: об'єкти роздрібної торгівлі, школи, дитячі садки, бібліотеки, клуби, об'єкти, що реалізують побутові послуги. На наш погляд, таки показники не можуть охарактеризувати рівень розвитку соціальної інфраструктури, а скоріше рівень розвитку надання соціальних послуг.

Л.Л. Сотниченко [14, с. 337] визначає рівень розвитку інфраструктури в регіонах України, але по суті інфраструктура регіону зводиться до транспортної інфраструктури. Для розрахунків на основі статистичної інформації щодо довжини доріг, площі регіонів, чисельності населення та валової продукції виробничих підприємств використовувались:

1) коефіцієнт Успенського, що розраховувався методом k-середніх та відображає рівень забезпеченості виробництва автомобільними дорогами;

2) коефіцієнт Енгеля;

3) рівень розвитку транспортної інфраструктури (за рівнем зайнятості);

4) ступень використання транспортної інфраструктури (за рівнем зайнятості) для регіонів України.

Необхідно зазначити, що коефіцієнт Успенського найчастіше використовують для оцінки забезпеченості тієї чи іншої території транспортними комунікаціями, але його також використовують і для оцінки забезпечення інфраструктури в цілому. Для цього використовують цей коефіцієнт при оцінці міст, або інших територіальних поселень, шляхом визначення їх забезпеченості елементами локальної території у вартісному вигляді за показниками зайнятості населення чи основних фондів. У такому випадку, наприклад, при оцінці соціальної інфраструктури за основними 
фондами, коефіцієнт Успенського (К) може бути представлений у наступному вигляді:

$$
\mathrm{K}=\frac{F}{\sqrt[3]{P \cdot S \cdot Q}},
$$

де: $F$ - основні фонди соціальної інфраструктури, млн. грн.;

$P$ - чисельність населення, млн. осіб.;

$S$ - площа економічно активної території, що належить муніципальному утворенню, тис. км²

$Q$ - валова продукція товарів підприємств, вироблена на даній території, млн. грн.

Але, використання коефіцієнту Успенського має певні вади, які можливо усунути за рахунок використання методик, що нівелюють відмінності у вартості основних фондів різних елементів соціальної інфраструктури 3 урахуванням економічно активної площі локальної території. При цьому, коефіцієнт Успенського враховує як обсяги виробленої продукції так і чисельність населення, що дає можливість на основі його обрахунків прогнозувати розвиток соціальної інфраструктури по відношенню до споживачів та виділити пріоритетні напрями першочергового інвестування.

3 приводу використання коефіцієнту Енгеля у методиці, яка запропонована Л.Л. Сотниченко [14, с. 337], необхідно відзначити, що цей коефіцієнт також може бути модифікований під розрахунок не тільки оцінки транспортної інфраструктури, а й соціальної інфраструктури в цілому.

I.O. Абрамова $[1$, с. 8] визначає соціально-економічний розвиток регіонів за трьома критеріями:

1) граничного рівня відхилення соціально-економічних показників від середніх показників розвитку територій, що визначається як добуток середнього показника розвитку території відповідної групи та коефіцієнта 0,75 - для показників стимуляторів і 1,25 - для дестимуляторів;

2) динаміки ВРП як узагальнюючого показника соціально-економічного розвитку регіону;

3) оцінки порогових значень безпеки соціально-економічного розвитку регіону. Дослідник використовує такі показники соціально-економічного розвитку як: народжуваність та смертність, кількість злочинів, навантаження на одну вакансію та рівень безробіття, забезпечення населення житлом, доходи населення на одну особу. Для встановлення безпеки соціальноекономічного розвитку - кількість інвестицій в основний капітал; обсяги експорту та імпорту товарів і послуг; коефіцієнт покриття експортом імпорту; кількість малих підприємств. 
Автор пропонує методику визначення рівня кризовості соціальногоекономічного розвитку, але по суті визначається кризовість соціальноекономічного стану регіонів. При цьому розвиток може бути як регресуючим так і прогресуючим.

Проведене дослідження робіт науковців щодо визначення розвитку соціальної інфраструктури дає можливість визначити найбільш часто вживані показники, які зведені та представлені у таблиці.

Таблиия

Аналіз використання часткових показників у методичних підходах до оцінки рівня розвитку соціальної інфраструктури регіонів

\begin{tabular}{|c|c|}
\hline Показник & \begin{tabular}{|l|} 
Кількість \\
використання \\
показника \\
\end{tabular} \\
\hline \multicolumn{2}{|l|}{ Охорона здоров'я } \\
\hline кількість лікарняних ліжок на 10 тис. & 2 \\
\hline кількість амбулаторно-поліклінічних закладів (АПЗ) & 3 \\
\hline кількість відвідувань за зміну АПЗ на 10 тис. населення & 2 \\
\hline кількість фельдшерських і акушерсько-фельдшерських пунктів & 2 \\
\hline кількість пологових будинків & 1 \\
\hline кількість лікарських ліжок для вагітних і роділь на 10 тис. жінок & 1 \\
\hline кількість лікарів усіх спеціальностей (на 10 і тис. населення) & 4 \\
\hline кількість середнього медичного персоналу (на 10 тис. населення) & 1 \\
\hline $\begin{array}{l}\text { середньорічна кількість найманих працівників охорони здоров’я } \\
\text { соціальної допомоги (на } 10 \text { тис. населення) }\end{array}$ & 1 \\
\hline забезпеченість населення медичними кадрами на 10 тис. населення & 2 \\
\hline обсяг надання послуг у сфері охорони здоров’я (на 1 особу) & 2 \\
\hline $\begin{array}{l}\text { відношення кількості місць у санаторно-курортних і оздоровчих закладах } \\
\text { до чисельності населення }\end{array}$ & 1 \\
\hline чисельність оздоровлених у санаторно-курортних і оздоровчих закладах & 3 \\
\hline $\begin{array}{l}\text { чисельність оздоровлених дітей у відсотках до загальної чисельності дітей } \\
\text { 7-16 років }\end{array}$ & 1 \\
\hline \multicolumn{2}{|l|}{ Фізична культура та спорт } \\
\hline кількість дитячо-юнацьких спортивних шкіл & 2 \\
\hline питома вага дітей у ДЮСШ у загальній чисельності населення & 2 \\
\hline кількість спеціалізованих дитячо-юнацьких шкіл олімпійського резерву & 1 \\
\hline \multicolumn{2}{|l|}{ Наука й освіта } \\
\hline $\begin{array}{l}\text { охопленість дітей дошкільними закладами (у відсотках до кількості дітей } \\
\text { відповідного віку) }\end{array}$ & 1 \\
\hline кількість учнів на одного вчителя & 1 \\
\hline кількість загальноосвітніх навчальних закладів & 2 \\
\hline кількість вищих навчальних закладів I-IV рівнів акредитації & 2 \\
\hline кількість студентів вищих навчальних закладів I-IV рівнів акредитації & 2 \\
\hline кількість учнів і слухачів ПТНЗ на 10 тис. населення & 1 \\
\hline наявність парку обчислювальної техніки & 1 \\
\hline
\end{tabular}




\begin{tabular}{|c|c|}
\hline \multicolumn{2}{|l|}{ Екологічний стан } \\
\hline потужність очисних споруд & 1 \\
\hline скидання забруднених зворотних вод у поверхневі водні об’єкти & 1 \\
\hline $\begin{array}{l}\text { викиди забруднюючих речовин в атмосферне повітря від стаціонарних та } \\
\text { пересувних джерел забруднення }\end{array}$ & 1 \\
\hline $\begin{array}{l}\text { викиди забруднюючих речовин в атмосферне повітря від стаціонарних та } \\
\text { пересувних джерел забруднення у розрахунку на одну особу }\end{array}$ & 1 \\
\hline \multicolumn{2}{|l|}{ Культура та мистецтво } \\
\hline кількість місць у залах для демонстрування фільмів на 100 жителів & 1 \\
\hline кількість місць у закладах культури клубного типу на 100 жителів & 1 \\
\hline книжковий фонд бібліотек примірників на 100 жителів & 1 \\
\hline \multicolumn{2}{|l|}{ Роздрібна торгівля, громадське харчування, послуги населенню } \\
\hline обсяг реалізованих послуг на душу населення & 1 \\
\hline $\begin{array}{l}\text { роздрібний товарообіг підприємств на душу населення (у т.ч ресторанного } \\
\text { господарства) }\end{array}$ & 1 \\
\hline забезпеченість населення торговими площами магазинів & 1 \\
\hline \multicolumn{2}{|l|}{ Житлово-комунальне господарство } \\
\hline забезпеченість населення житлом & 2 \\
\hline кількість готелів та інших місць для тимчасового проживання & 1 \\
\hline $\begin{array}{l}\text { коефіцієнт використання місткості готелів та ін. місць для тимчасового } \\
\text { проживання }\end{array}$ & 1 \\
\hline \multicolumn{2}{|l|}{ Транспорт } \\
\hline вантажооборот за усіма видами транспорту & 1 \\
\hline пасажирооборот за усіма видами транспорту & 1 \\
\hline $\begin{array}{l}\text { щільність автомобільних доріг загального користування з твердим } \\
\text { покриттям }\end{array}$ & 1 \\
\hline щільність залізничних колій загального користування & 1 \\
\hline \multicolumn{2}{|l|}{ Соціальний рівень } \\
\hline ВРП на душу населення & 6 \\
\hline природний приріст населення & 1 \\
\hline рівень безробіття & 3 \\
\hline зайнятість населення у віці 15-70 років & 3 \\
\hline рівень інфляції (індекс споживчих цін) & 1 \\
\hline середньомісячна заробітна плата & 2 \\
\hline доходи населення & 2 \\
\hline тривалість життя чоловіків та жінок & 2 \\
\hline загальні коефіцієнти народжуваності та смертності & 1 \\
\hline чисельність наявного населення на початок року & 2 \\
\hline частка населення з доходами нижче за розмір прожиткового мінімуму & 1 \\
\hline кількість померлих у віці до 1 року, осіб /1000 народжених & 1 \\
\hline $\begin{array}{lllll}\text { співвідношення між доходами } & 10 \% & \text { найбільш } \\
\text { низькодохододохідних } & \text { і } & 10 \% \\
\end{array}$ & 1 \\
\hline
\end{tabular}
$13 ; 14 ; 16]$

Джерело: складено та узагальнено авторами на основі аналізу $[1 ; 2 ; 3 ; 4 ; 5 ; 6 ; 8 ; 9 ; 11 ; 10 ; 12$;

Отже, наведені найбільш часто вживані показники, що використовуються для оцінки соціальної інфраструктури дають можливість стверджувати, що 
частіш за все ці показники $€$ показниками які наводяться Державним управлінням статистики та не існує єдиного загально визначеного набору часткових показників для оцінки соціальної інфраструктури.

Висновки. Наукова новизна дослідження полягає в обгрунтуванні пропозицій щодо удосконалення методичного підходу оцінки розвитку соціальної інфраструктури регіонів, що базується на аналізі існуючих методичних підходів та використанні в них часткових показників оцінки соціальної інфраструктури та враховує позитивні й негативні сторони методичних підходів, а саме:

- частіше за все дослідники використовують, для оцінки поточного стану соціальної інфраструктури та змін іiі динаміки за роками метод агрегатного індексування. Сутність використання цього методу пояснюється тим, що побудова узагальнюючого показника дає можливість виявити взаємообумовлюючий вплив показників соціального та економічного розвитку регіонів, ступінь міжрегіональної асиметрії розвитку, особливості динамічних змін тощо;

- для оцінки саме розвитку доречно використовувати такі статистичні методи - коефіцієнт варіації, дисперсію, середньоквадратичне відхилення, а також методи групування, стандартизації показників, визначення сумарних та інтегральних показників тощо;

- незважаючи на те, що для оцінки розвитку соціальної інфраструктури та ii підсистем використовують різноманітний методичний інструментарій дослідження, можна зазначити відсутність у методиках орієнтації на встановлення певних залежностей розвитку системи, що в сучасних умовах економічної дестабілізації набуває особливої актуальності;

- більшість методичних підходів оцінки розвитку соціальної інфраструктури регіонів базуються на використанні інструментарію визначення інтегральної оцінки за різними показниками, які об'єднані у певні підгрупи, що характеризують багатоаспектні процеси соціальної інфраструктури. Інтегральний показник розраховується або за допомогою коефіцієнтів вагомості, $з$ урахуванням думки експертів, або за рахунок встановлення відхилення нормованих значень часткових показників від еталонного, за який частіше за все приймається максимальне значення часткового показника в певному регіоні;

- після оцінки стану розвитку соціальної інфраструктури в регіонах, для розроблення подальших варіантів розвитку, 3 врахуванням регіональної специфіки й впливу зовнішніх факторів, прийняття управлінських рішень, заходів пожвавлення розвитку соціальної інфраструктури, особливе місце займає використання методів економіко-математичного моделювання, що дозволяє мінімізувати витрати праці й часу при обробленні параметрів 
розвитку соціальної інфраструктури шляхом групування регіонів, залежно від отриманого значення індексу розвитку соціальної інфраструктури.

Загальними рисами досліджуваних методів оцінки розвитку соціальної інфраструктури $\epsilon$ те, що вони базуються на виділенні груп часткових показників, які характеризують систему у цілому, розраховується інтегральний показник розвитку соціальної інфраструктури, здійснюється ранжування регіонів за рейтингом у залежності від отриманих результатів, що допомагає при розробленні стратегії розвитку, на основі сформульованих прогнозів та визначенні заходів, які забезпечують їх реалізацію.

Практичне значення отриманих результатів полягає у використанні результатів аналітичного дослідження для удосконалення методичного підходу оцінки розвитку соціальної інфраструктури, що дасть можливість регіональним органам влади розробити заходи щодо активізації ії розвитку.

Подальших досліджень потребує розроблення пропозицій 3
удосконалення методичного підходу оцінки розвитку соціальної інфраструктури регіонів, що дасть можливість не тільки оцінити розвиток соціальної інфраструктури регіонів, а й розробити пропозиції щодо активізації розвитку.

\section{Література:}

1. Абрамова I. О. Аналіз соціально-економічного розвитку регіонів України на предмет кризовості / І. О. Абрамова // Економічний аналіз. - 2014. - Т. 15. № 1. - С. 6-15.

2. Аналітичний центр «Бюро економічних та соціальних досліджень». [Електронний pecypc]. - Режим доступу : http://www.esoc.org.ua/index.php

3. Бондар С. І. Розвиток соціальної інфраструктури села в ринкових умовах / С. I. Бондар // Автореф. дис. на здобуття наукового ступеня кандидата економічних наук. - Харків, 2005. $-20 \mathrm{c}$.

4. Гринько О. В. Формування методики оцінки рівня розвитку соціальної інфраструктури сільських територій / О. В.Гринько // Електронне наукове фахове видання Ефективна економіка. - № 7, 2012. [Електронний ресурс]. - Режим доступу : http://www.economy.nayka.com.ua/?op=1\&z=1290

5. Дубіщев В. П. Методологічні засади дослідження соціального потенціалу регіону / В. П. Дубіщев, В. М.Прохорова // Економічний вісник Запорізької державної інженерної академії. - 2011. - Вип. 1. - С. 56-62.

6. Лісовий А. Методичні підходи до оцінювання сільської соціальної інфраструктури в Україні / А. Лісовий // Економіка України. - 2007. - №5. - С. 52-55.

7. Ляшенко О. Визначення інтегрального показника рівня розвитку соціальної інфраструктури сільських територій / О. Ляшенко // Вісник Полтавської державної аграрної академії. Науково-виробничий фаховий журнал. - 2011. - С. 112-117.

8. Мифтахова М. Э. Вейвлет-анализ динамики региональной системы / М. Э. Мифтахова М. В. Панаеюк // Ученые записки Казанского государственного университета. Серия; Естественные науки. 2009, Т. 151. № 1. - С. 247-262.

9. Омельченко О. І. Методологічні засади оцінювання рівня життя населення в регіонах України /О. І. Омельченко // Проблеми економіки. - 2010. - № 2. - С. 81-90. 
10. Панько М. В. Проблеми та перспективи розвитку соціальної складової структури економіки закарпатської області / М. В. Панько // Економічний аналіз. - 2014. - Том 18. № 1. - С. 177-182.

11. Подік О. А. Розвиток інфраструктури регіону як один із головних важелів розвитку галузі свинарства / О. А. Подік // Економіка АПК. - 2009. - № 21. - С. - 53-56.

12. Саєнко М. Обгрунтування методичних підходів щодо оцінки стану і розвитку соціальної інфраструктури сільських територій / М. Саєнко, А. Сава // Зб. наук. пр. «Торгівля і ринок». - В. 36. - 2013. - С. 266-278.

13. Соляр В. В. Обгрунтування перспективних напрямів розвитку соціальної інфраструктури регіону / В. В. Соляр // Регіональна економіка. - 2012. - № 1. - С. 200207.

14. Сотниченко Л. Л. Визначення рівня розвитку інфраструктури регіонів України / Л. Л. Сотниченко // Вісник донецького національного університету, Сер. В : економіка і право, вип. 1. - 2015. - С. 335-341.

15. Тульчинська С. О. Органічність функціонування інтелектуально-інноваційної системи регіонів: Монографія [Текст] / С. О. Тульчинська. - Херсон : Ви-во «ПП Вишемирський В.С.», 2012. - 400 с.

16. Чернюк Л. Г. Соціальна інфраструктура та їі пріоритетність у системі суспільного розвитку (методолого-організаційний аспект) / Л. Г. Чернюк, Т. В. Пепа // Вісник Чернігівського технологічного університету : Серія: Економічні науки. - ЧНТУ, 2012. № 1 (56). - C. 10-20. 